\title{
Alphavirus Replicon Particles Are Highly Immunogenic in the Murine Malaria Model by Homologous or Heterologous Immunization
}

\author{
C. Dobaño*,1,2,3 W.R. Weiss ${ }^{1}$, K.I. Kamrud ${ }^{4}$, J.D. Chulay ${ }^{4}$, J. Smith ${ }^{4}$, D.J. Carucci ${ }^{\sharp, 1}$ and \\ D.L. Doolan ${ }^{1,5}$
}

${ }^{1}$ Malaria Program, Naval Medical Research Center, Silver Spring, MD 20910-7500, USA; ${ }^{2}$ Henry M. Jackson Founda-
tion, Rockville, MD 20852, USA; ${ }^{3}$ Barcelona Centre for International Health Research (CRESIB), Hospital Clinic /
IDIBAPS, Universitat de Barcelona, Barcelona E-08036, Spain; ${ }^{4}$ Alphavax Inc., Research Triangle Park, NC $27709-$
O307, USA and ${ }^{5}$ Department of Molecular Microbiology and Immunology, School of Hygiene and Public Health, Johns
Hopkins University, Baltimore, MD 21205-2179, USA

Abstract: We evaluated the immunogenicity of virus-like replicon particles (VRP) derived from an attenuated strain of the alphavirus Venezuelan equine encephalitis virus, encoding two pre-erythrocytic Plasmodium yoelii antigens, in mice. Three immunizing doses were superior to two, and the subcutaneous route was comparable to intramuscular and more immunogenic than intradermal, at doses between $5 \times 10^{5}-5 \times 10^{8}$ IU. VRP vaccines were capable of overcoming the traditionally low immunogenicity of the PyHEP17 antigen when delivered as a DNA vaccine, particularly evident with regard to enhancing specific IgG responses. Furthermore, a heterologous VRP prime and poxvirus boost regimen induced a significant enhancement of IFN- $\gamma$ responses as compared with homologous VRP or DNA immunization, which was equal or greater to that induced by DNA prime followed by poxvirus boost. These data demonstrate the potential of VRP as a vaccine delivery system to enhance protective immune responses to malaria.

\section{INTRODUCTION}

Malaria is a complex protozoan parasite with distinct stages in its lifecycle in both humans and mosquitoes [1]. Over the past two decades, it has been established that immune responses directed at the pre-erythrocytic (sporozoite and/or liver) or erythrocytic (blood) stages can reduce the morbidity and mortality of the disease [2, 3]. However, an as yet unresolved challenge has been to identify vaccine platforms capable of inducing robust and persistent immune responses (cellular and/or humoral) capable of protecting against pathogen challenge. To date, none of the existing vaccine delivery systems has been successful in achieving a clinically useful malaria vaccine [4].

Immunization of mice with plasmid DNA encoding the pre-erythrocytic stage Plasmodium yoelii antigens, circumsporozoite protein (PyCSP) [5] and hepatocyte erythrocyte protein $17 \mathrm{KDa}$ (PyHEP17) [6], induces antigen-specific antibody and cellular immune responses and confers sterile protection against sporozoite challenge. Nevertheless, immunogenicity and protective efficacy of these first generation DNA vaccines is suboptimal. Specifically, in mice immunized with DNA encoding $P$. yoelii pre-erythrocytic stage antigens, protection does not withstand high challenge doses, is not sustained for a long period (M. Sedegah and D.L. Doolan, unpublished), and is genetically restricted [7]. In

*Address correspondence to this author at the Barcelona Centre for International Health Research (CRESIB), Hospital Clínic / IDIBAPS, Universitat de Barcelona, Barcelona E-08036, Spain; E-mail: cdobano@clinic.ub.es

"Present addresses: D.J. Carucci: Foundation for the National Institutes of Health, 45 Center Drive, Bethesda, MD 20892-6300; D.L. Doolan, Queensland Institute of Medical Research, The Bancroft Centre, 300 Herston Road, PO Royal Brisbane Hospital, Brisbane, QLD 4029, Australia those mouse strains that are protected by vaccination against sporozoite challenge, PyCSP DNA induces relatively good $\mathrm{CD} 8^{+}$cytotoxic T lymphocyte (CTL) responses and antibody responses, but poor $\mathrm{CD}^{+} \mathrm{T}$ cell responses $[5,8]$ (W.R. Weiss, unpublished); and PyHEP17 DNA induces poor $\mathrm{CD} 8^{+} \mathrm{CTL}$ and $\mathrm{CD} 4^{+} \mathrm{T}$ cell responses and negligible antibody responses $[7,9]$. These suboptimal responses have led to the investigation of immune enhancement strategies for DNA vaccination [10]. Heterologous prime/boost strategies whereby DNA-primed immune responses are boosted with recombinant viral vectors (such as poxviruses or adenoviruses) have been shown to substantially enhance antigenspecific immune responses and improve protective immunity $[8,11-13]$.

Recent studies have suggested that molecular vaccines based on alphaviruses such as the Venezuelan equine encephalitis (VEE) virus may have several important advantages over DNA vaccines as gene delivery vectors $[14,15]$. Alphaviruses have a single-strand, positive-sense RNA genome approximately $11.4 \mathrm{~Kb}$ in length. The virus nonstructural proteins (nsP1-nsP2-nsP3-nsP4) are encoded in the 5' two-thirds of the genome while the structural proteins (capsid-E3-E2-6K-E1) are encoded in the 3' one-third of the genome. The genome is capped at the $5^{\prime}$ 'end and polyadenylated at the 3' end. The nonstructural proteins are translated in cells directly from the capped viral genomic RNA and the structural proteins are translated from a subgenomic RNA that is transcribed from a $26 \mathrm{~S}$ promoter that is present on the full-length negative-stranded RNA replication intermediate (reviewed in [16]). Alphavirus vector systems have been developed by removing the structural protein region and replacing it with heterologous genes resulting in a selfreplicating mRNA or replicon that expresses the heterolo- 
gous gene at high levels. The replicon RNA can be packaged into virus-like replicon particles (VRP) by providing the structural protein genes in trans on separate helper RNAs. VRP can infect fresh cells but no additional VRP are produced because the helper RNAs are not present to provide the structural proteins (i.e. the replicon infection is abortive). Transfected cells undergo apoptosis and are taken up by dendritic cells, leading to enhanced antigen presentation [17]. Alphavirus replicons have a broad tissue host range, the ability to infect both dividing and non-dividing cells, and can induce host immuno-stimulatory responses [18]. Because they induce apoptosis, such that transfected cells are destroyed and therefore do not produce antigen chronically, alphavirus replicons are considered replication-defective single-cycle vectors. These vectors have a high safety profile, reducing theoretical concerns about tolerance, autoimmunity, integration of plasmid sequences into the host's genome, and long-term persistence of foreign DNA in the host following DNA vaccination.

The VRP vaccine vector system has been shown to express heterologous proteins to high levels from the subgenomic RNA [19], to target expression to dendritic cells in animals [20], and to induce a balanced humoral and cellular immune response to the vectored gene product [21]. Other advantages include the low seroprevalence of anti-alphavirus antibodies in human populations, translating to minimal antivector immunity [16], in contrast to poxvirus- [22] or adenovirus- [23] based vaccine vectors where high levels of preexisting immunity to the vector in humans may compromise their usefulness. VRP vaccines have been shown to protect mice, guinea pigs and non-human primates against challenge with a variety of pathogens, including influenza A and Lassa fever [19, 24], Marburg virus [25], botulinum toxin [26], SIV [27], anthrax [28], Ebola virus [24, 29, 30], SIV [31], and Neisseria gonorrhoeae [32]. Furthermore, analysis of blinded results from the first Phase 1 clinical trial evaluating a VRP vaccine, indicates that the vaccine induced an antibody response in $100 \%$ of the recipients at the highest dose tested and in a majority of the recipients at a 10-fold lower dose. In addition, the vaccine was well-tolerated and no vaccine-related safety issues were identified (data presented by AlphaVax at the AIDS Vaccine 2006 Conference, Amsterdam, The Netherlands).

Here, we report on the evaluation of VRP vaccines derived from an attenuated strain of the alphavirus VEE virus, in a malaria rodent model, in either homologous or heterologous (DNA, poxvirus) prime-boost immunization regimens. We compared immune responses induced by immunization with VRP encoding PyCSP and PyHEP17 administered at different dosages $\left(5 \times 10^{5}\right.$ to $5 \times 10^{8}$ infectious units (IU)) and by three different routes, subcutaneous (SC), intramuscular (IM) and intradermal (ID).

\section{MATERIALS AND METHODS}

\section{Construction of VEE Viral Replicon Particle Vaccines Encoding Plasmodium Genes}

The single-promoter vector plasmid, pERK, is a derivative of pVR21 [19] that has been modified to contain an expanded multiple-cloning site and contains the kanamycin resistance gene instead of the ampicillin resistance gene as the selectable marker. The multiple cloning site contains the following restriction sites: 5' EcoRV, AscI, PmeI, FseI, PacI 3'. To maintain the correct position of the ATG start codon of the gene of interest relative to the position it would be in a wild type 26S VEE mRNA, genes were cloned into the 5' EcoRV site and any of the remaining 3' sites. The pERK plasmid was used to engineer the single-promoter replicon RNAs expressing PyCSP or PyHEP17.

\section{Production of VRP}

RNA transcripts were produced in vitro (Promega RiboMAX transcription kits) from the two VEE structural protein gene helper plasmids (capsid (c) and glycoproteins E1 and E2) and the VEE replicon vector plasmid encoding the malarial antigen. The three RNA transcript preparations were separately purified by either spin-column (gel binding and elution) or size-exclusion chromatography, followed by agarose gel analysis to confirm expected size, and quantitated by UV absorbance. The three RNA preparations were combined with $1 \times 10^{8}$ Vero cells resuspended in PBS. The RNA and cell suspension were introduced into a $0.4 \mathrm{~cm}$ electroporation cuvette and pulsed four times with a BIO-RAD Gene Pulser (BIO-RAD, Hercules, CA) set to deliver 580 volts at $25 \mu \mathrm{F}$. After electroporation, the cells were incubated at room temperature for $10 \mathrm{~min}$ and seeded into flasks containing serum-free OptiPro medium (Invitrogen, Carlsbad, CA). The cultures were incubated at $37^{\circ} \mathrm{C}$ in $5 \% \mathrm{CO}_{2}$ for $18-24 \mathrm{~h}$. VRP were collected from transfected cells and concentrated and purified by binding to, and elution from, pre-packed, Heparin Fast Flow columns (Pharmacia). VRP were prepared for immunization in PBS/1\% normal mouse serum.

\section{Plasmid DNA and Recombinant Poxvirus Vaccines}

Plasmid DNA vaccines used for immunization, based on the VR1020 backbone [33], were obtained from Vical Inc. (San Diego, CA): VR2515 encoding PyHEP17 [6, 7], and VR2516 encoding PyCSP [5]. Recombinant vaccinia virus (poxvirus) vaccines used for immunization were COPAK derivatives, where a K1L gene has been inserted into the New York Vaccinia (NYVAC) virus: VP1258 ABL-9 C28 encoding PyCSP [8], and VCPY1 B49-58 encoding PyHEP17 (K. Limbach, unpublished).

\section{Recombinant Proteins and Synthetic Peptides}

The sequences of synthetic peptides based on the PyHEP17 or PyCSP proteins used for in vitro stimulation in $\mathrm{T}$ cell assays or as capture antigen in ELISA assays are provided in Table 1. Recombinant PyHEP17 protein produced in an $E$. coli based cell-free in vitro transcription/translation system (RTS100, Roche Biosciences, Indianapolis, IN) was also used for in vitro $\mathrm{T}$ cell stimulation and as a capture antigen for ELISA assays.

\section{Mice and Immunizations}

Female 5- to 8-wk-old BALB/cByJ were obtained from The Jackson Laboratory (Bar Harbor, ME). In two VRP dose titration studies, mice ( $n=6 /$ group) were immunized 1 or 2 times with $1 \times 10^{5}, 1 \times 10^{6}$, or $1 \times 10^{7}$ IU IM, or $1 \times 10^{7}$ IU SC, of VRP encoding PyCSP. In a separate experiment, mice ( $\mathrm{n}=5$ /group) were immunized 2 times with doses ranging from $5 \times 10^{5}$ to $5 \times 10^{7}$ IU of VRP encoding PyHEP17, via IM or SC routes. In route of administration studies, mice $(n=6 / g r o u p)$ were immunized 3 times at $4 \mathrm{wk}$ intervals with 
$50 \mu \mathrm{g}$ plasmid DNA IM or $5 \times 10^{6}$ IU of VRP encoding either PyCSP or PyHEP17 or an unrelated control (GFP or influenza HA) via the IM, SC or ID route. For IM injections, the vaccines were injected into each tibialis anterior muscle in a volume of $50 \mu \mathrm{l}$ PBS, using a $0.3 \mathrm{ml}$ insulin syringe fitted with a plastic collar cut from a micropipette tip, adjusted to limit the needle penetration to a distance of about $2 \mathrm{~mm}$ into the muscle. For ID injections, the back of the mouse was shaved and $100 \mu l$ of vaccine was injected intradermally into four sites to generate a bleb (which persisted more than 30 sec), using a $0.3 \mathrm{ml}$ insulin syringe. For SC injections, $50 \mu 1$ of vaccine was injected into the footpads of the mouse, using a $0.3 \mathrm{ml}$ insulin syringe. In homologous immunization regimens, mice were immunized 2 or 3 times with $5 \times 10^{6}$ IU of VRP at 4- or 6-week intervals. In one study, an additional boost was given 4.5 months after the $2^{\text {nd }}$ or $3^{\text {rd }}$ dose to assess the durability of immune response. In heterologous immunization regimens, mice were primed with $50 \mu \mathrm{g}$ of plasmid DNA or $5 \times 10^{6}$ IU of VRP and boosted with $50 \mu \mathrm{g}$ of plasmid DNA, $5 \times 10^{6}$ IU of VRP or $2 \times 10^{7}$ pfu of poxvirus by the IM route. Sera were collected approximately $3 \mathrm{wk}$ after each immunization for antibody studies. Mice were sacrificed for $\mathrm{T}$ cell studies at 3 or $5 \mathrm{wks}$ after the second or third immunization. All experiments reported herein were conducted in compliance with the Animal Welfare Act and in accordance with the principles set forth in the "Guide for the Care and Use of Laboratory Animals", Institute of Laboratory Animal Resources, National Research Council, National Academy Press, 1996.

\section{Antibody Assays}

Serum samples ( $\mathrm{n}=6$ mice/group, pooled) were serially diluted two-fold and assayed for antigen-specific and parasite-specific antibody responses. Antigen-specific antibodies were measured by enzyme-linked immunosorbent assay (ELISA) against recombinant PyCSP full-length protein (0.1 $\mu \mathrm{g} / \mathrm{ml})$, PyHEP17 MR68 peptide $(0.1 \mu \mathrm{g} / \mathrm{ml})$, or recombinant PyHEP17 protein $(2 \mu \mathrm{g} / \mathrm{ml})$, as previously described $[34,35]$. Results were reported as antibody titers at $\mathrm{OD}_{405}$. Parasite-specific antibodies were assessed by indirect fluorescent antibody test (IFAT) against air-dried $P$. yoelii sporozoites for PyCSP or air-dried $P$. yoelii infected erythrocytes for PyHEP17, as previously described [34]. Results were reported as the endpoint dilution, representing the last serum dilution at which fluorescence was scored as positive.

\section{Interferon- $\boldsymbol{\gamma}$ ELIspot Assay}

Multiscreen MAHAS 4510 plates (Millipore, Bedford, MA) were coated with $60 \mu 1 /$ well of sterile carbonate/bicarbonate buffer containing $10 \mu \mathrm{g} / \mathrm{ml}$ of anti-murine IFN- $\boldsymbol{\gamma}$ (R4, Pharmingen, San Diego, CA) and incubated overnight at room temperature. Plates were washed twice with $200 \mu 1 /$ well RPMI medium and twice with complete RPMI (cRPMI) medium containing Penicillin/Streptomycin, L-Glutamine and $10 \% \mathrm{FBS}$, and incubated with $200 \mu \mathrm{l} /$ well of cRPMI medium in $5 \% \mathrm{CO}_{2}$ at $37^{\circ} \mathrm{C}$ for at least $3 \mathrm{~h}$. After blocking, the plates were washed once more with cRPMI before the addition of target and effector cells. A20.2J (ATCC clone HB-98) or P815 (ATCC TIB 64) target cells were washed once with cRPMI, incubated at $5 \times 10^{6}$ cells $/ \mathrm{ml}$ with or without PyCSP peptide $(10 \mu \mathrm{g} / \mathrm{ml})$ or PyHEP17 peptide $(20 \mu \mathrm{g} / \mathrm{ml})$ or PyHEP17 protein $(200 \mu \mathrm{g} / \mathrm{ml})$ for $1 \mathrm{~h}$ at $37^{\circ} \mathrm{C}$ in $5 \% \mathrm{CO}_{2}$, and irradiated in a ${ }^{137} \mathrm{Cs}$ gamma irradiator (A20.2J at 16,000 rads or P815 at 10,000 rads). Next, target cells were washed 3 times with cRPMI, diluted to $1.5 \times 10^{6}$ cells $/ \mathrm{ml}$ (A20.2J) or $1.0 \times 10^{6}$ cells $/ \mathrm{ml}$ (P815) in cRPMI. To obtain effectors, immunized single cell suspensions prepared from pooled spleens were washed 3 times, counted and di-

\section{Table 1. Synthetic Peptide Sequences}

\begin{tabular}{|c|c|c|}
\hline \multicolumn{3}{|c|}{ PyHEP17 peptides $[9,36]$} \\
\hline \multicolumn{3}{|c|}{ Defined $\mathrm{CD} 4^{+} \mathrm{T}$ cell epitope with nested $\mathrm{CD} 8+\mathrm{T}$ cell epitopes } \\
\hline Residues 61-75 & EEIVKLTKNKKSLRK & Dominant \\
\hline Residues 71-85 & KSLRKINVALATAL & Dominant \\
\hline \multicolumn{3}{|c|}{ Defined $\mathrm{CD} 8^{+} \mathrm{T}$ cell epitopes } \\
\hline Residues 74-84 & RKINVALAT & Subdominant \\
\hline \multicolumn{3}{|c|}{ Defined B cell epitope (peptide MR68) } \\
\hline Residues 126-140 & SFPMNEESPLGFSPE & Dominant \\
\hline \multicolumn{3}{|c|}{ PyCSP peptides [37-40] } \\
\hline Residues 59-79 & YNRNIVNRLLGDALNGKPEEK & Subdominant \\
\hline \multicolumn{3}{|c|}{ Defined $\mathrm{CD} 8^{+} \mathrm{T}$ cell epitopes } \\
\hline Residues 280-288 & SYVPSAEQI & Dominant \\
\hline Residues 58-67 & IYNRNIVNRL & Subdominant \\
\hline
\end{tabular}


luted to $5 \times 10^{6}$ cells $/ \mathrm{ml}$ and $2.5 \times 10^{6}$ cells $/ \mathrm{ml}$. Effector and target cells preparations were added to the IFN- $\gamma$ coated wells in quadruplicate at $100 \mu \mathrm{l} / \mathrm{well}$, and incubated in 5\% $\mathrm{CO}_{2}$ at $37^{\circ} \mathrm{C}$ for $36 \mathrm{~h}$. Plates were washed 3 times with PBS followed by 4 times with PBS-T (PBS 0.05\% Tween20). 100 $\mu 1 /$ well of biotinylated anti-IFN- $\gamma$ (XMG1.2, Pharmingen, San Diego, CA) at $2 \mu \mathrm{g} / \mathrm{ml}$ in PBS-T were added to the plates and incubated overnight at $4^{\circ} \mathrm{C}$. Plates were washed 6 times with PBS-T and $100 \mu 1 /$ well peroxidase conjugated streptavidin (Kirkegaard \& Perry, Gaithersburg, MD) was added at 1:800 dilution in PBS-T. After $1 \mathrm{~h}$ incubation at room temperature, plates were washed 6 times with PBS-T followed by 3 times with PBS alone, and developed with DAB reagent (Kirkegaard \& Perry, Gaithersburg, MD) according to manufacturer's instructions. After $15 \mathrm{~min}$, the plates were rinsed extensively with $\mathrm{dH}_{2} \mathrm{O}$ to stop the colorimetric reaction, dried and stored in the dark. Spots were counted with a KS ELIspot reader (Carl Zeiss Vision, Germany).

\section{Intracellular Cytokine Staining Assay}

A20.2J cells were pulsed with PyCSP or PyHEP17 antigens (same concentrations as for ELIspot) for $1 \mathrm{~h}$ at $37^{\circ} \mathrm{C}$ in $5 \% \mathrm{CO}_{2}$, or not pulsed (controls), and irradiated as above. Then, $100 \mu \mathrm{l} / \mathrm{well}$ of effector cells $\left(5 \times 10^{6}\right.$ cells $\left./ \mathrm{ml}\right)$ and 100 $\mu 1 /$ well A20.2J target cells $\left(1.5 \times 10^{6}\right.$ cells $\left./ \mathrm{ml}\right)$ pulsed with or without antigens were incubated in duplicate in U-bottom 96-well plates (Costar) in the presence of $1 \mu \mathrm{M}$ Brefeldin A (GolgiPlugTM, Pharmingen, San Diego, CA) in $5 \% \mathrm{CO}_{2}$ at $37^{\circ} \mathrm{C}$ for $16 \mathrm{~h}$. Plates were spun at $1,200 \mathrm{rpm}$ for $5 \mathrm{~min}$, the supernatant flicked out, and the cell pellet resuspended by gentle vortexing of the plate. Cell surface markers were stained with a combination of $0.3-0.5 \mu \mathrm{l} / \mathrm{well}$ of anti-CD8APC, anti-CD4-PERCP, anti-DX5-FITC or anti-CD62LFITC Abs (Pharmingen, San Diego, CA) in a final volume of $100 \mu \mathrm{l}$ of FACS wash (Becton Dickinson Immunocytometry Systems, San Jose, CA), on ice in the dark for $20 \mathrm{~min}$. After the surface staining, cells were washed with FACS wash twice, gently resuspended, and incubated with $90 \mu \mathrm{l}$ of Perm/Fix buffer (Pharmingen, San Diego, CA) for 20 min on ice in the dark. Next, cells were washed with $100 \mu \mathrm{l}$ of Perm/Wash buffer and intracellular IFN- $\gamma$ stained with 0.5 $\mu 1 /$ well of anti-IFN- $\gamma$-PE Abs (Pharmingen, San Diego, CA) in a final volume of $100 \mu \mathrm{l}$ in Perm/Wash buffer. After 20 min incubation on ice in the dark, cells were washed twice with Perm/Wash, once with FACS wash, resuspended in 100 $\mu l$ of FACS wash and stored at $4^{\circ} \mathrm{C}$ prior to analysis. Antigen-specific IFN- $\gamma$ intracellular production was determined by performing four-color fluorescent activated cell sorting using the FACSCaliburTM (Becton Dickinson Immunocytometry Systems, San Jose, CA) with CellQuest software.

\section{Cytokine Assays}

Sera collected 3 weeks post third immunization were assayed using the Cytometric Bead Array kit (Becton Dickinson, San Jose, CA) against a mouse $\mathrm{T}_{\mathrm{H}} 1 / \mathrm{T}_{\mathrm{H}} 2$ panel comprising the following cytokines: IFN- $\gamma$, TNF- $\alpha$, IL-2, IL-4, and IL-5.

\section{Statistical Analysis}

Experimental outcomes are presented as direct results of ELIspot assays (IFN- $\gamma$ spot forming cells (SFC)/million splenocytes), intracellular cytokine staining (ICS) and fluorescent activated cell sorting (FACS) analysis (\% population), ELISA (antibody titers at $\mathrm{OD}_{405}$ ) or IFAT (geometric mean of antibody titers). ELIspot and ICS data are reported as mean \pm standard deviation, and background responses were subtracted from the results of the test samples. For logistical reasons, due to the number of vaccination regimens compared, the large number of mice and peptides tested, and the complexity of immunological assays performed, it was not feasible to test each individual mouse spleen/serum separately on the day of the assay. While this approach has the advantage that pooling multiple spleens/sera per test reduces the inter-animal variability inherent in evaluation of immune responses, it has the limitation that statistical analyses can not be performed to compare magnitude of immune responses between groups. Serum cytokine concentrations were tested in individual mice, analyzed as median and percentiles $(25 \%$ and $75 \%)$ and vaccination groups were compared by the non-parametric Mann-Whitney U test.

\section{RESULTS}

\section{Dose Titration of VRP Vaccines}

Antibody and $\mathrm{T}$ cell responses were compared among mice immunized with doses ranging from $1-5 \times 10^{5}$ to $1-5 \times 10^{7}$ IU of PyCSP or PyHEP17 VRP. For PyCSP VRP, a dosedependent antigen-specific IFN- $\gamma \mathrm{T}$ cell response was noted using ELIspot and ICS assays, the highest responses being obtained with the highest dose of $1 \times 10^{7} \mathrm{IU}$ (data not shown). For PyHEP17 VRP, comparable antibody responses, measured by IFAT, and IFN- $\gamma$ ELIspot responses were obtained with $5 \times 10^{6}$ or $5 \times 10^{7}$ IU of PyHEP17 VRP (data not shown). A dose of $5 \times 10^{6}$ IU of VRP for both antigens was selected for subsequent immunization experiments.

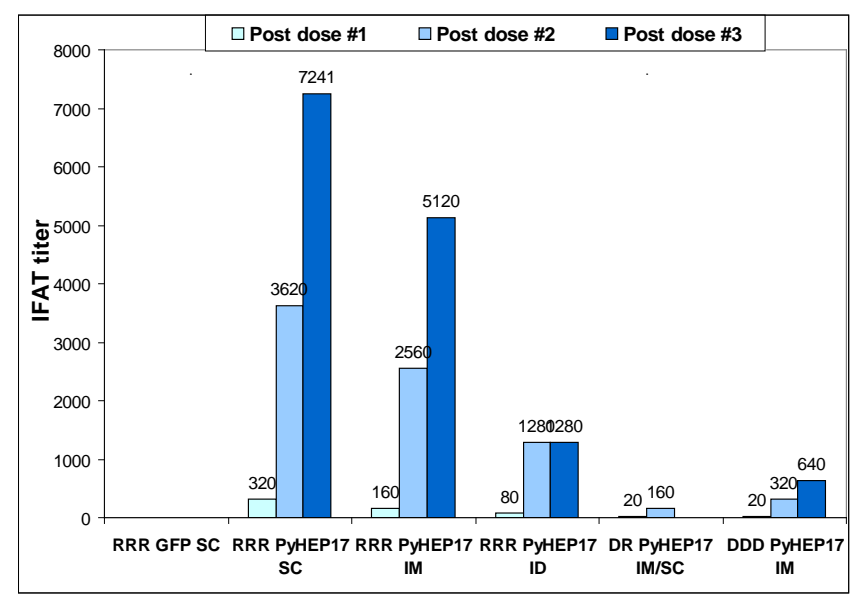

Fig. (1). Parasite-specific antibody responses induced by immunization with PyHEP17 VRP, measured by IFAT. Antibody titers (geometric means) to PyHEP17 expressed on P. yoelii infected erythrocytes, induced by various routes of administration and numbers of doses, with PyHEP17 VRP homologous and heterologous immunization regimens. Data show results with pooled sera $(n=6)$ collected after $\sim 3$ weeks post each immunization. $\mathrm{R}=\mathrm{VEE}$ VRP; $\mathrm{D}=$ DNA plasmid.

$\mathrm{SC}=$ subcutaneous; $\mathrm{IM}=$ intramuscular; $\mathrm{ID}=$ intradermal. 


\section{Route of Administration of VRP Vaccines}

\section{Antibody Responses}

Immunization with VRP encoding the PyHEP17 antigen via either the IM or SC route of administration induced a dramatic and specific 8-10 fold enhancement of antibody titers to whole $P$. yoelii parasites, compared to DNA immunization, as measured by IFAT (Fig. 1). In addition, PyHEP17 VRP by the ID route induced a 2-4 fold stronger antibody response but this route was not as immunogenic for antibody responses as the IM or SC routes (Fig. 1). Similar

\section{A. Peptide PyHEP17}
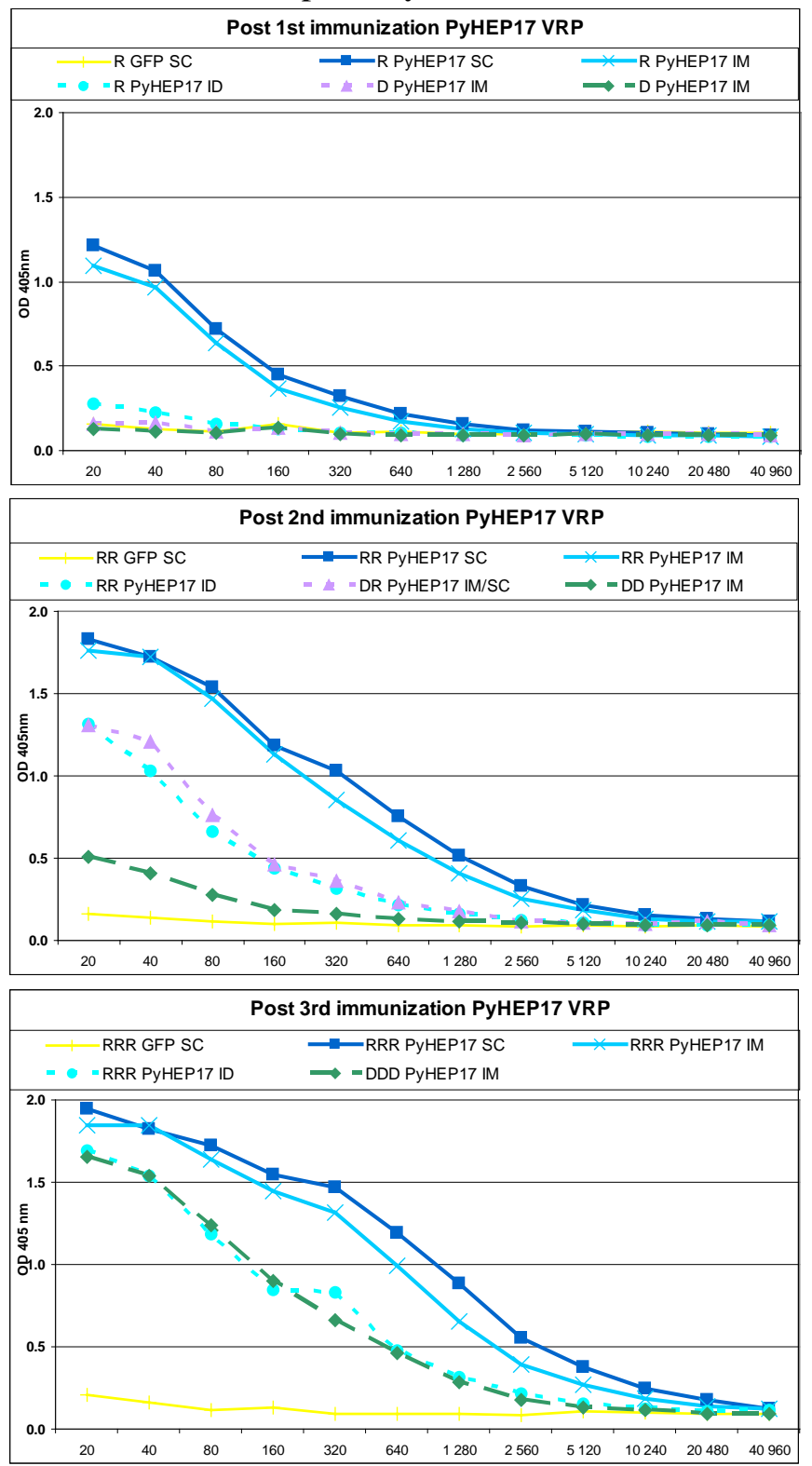

results were obtained when PyHEP17-specific antibodies were measured by ELISA using the MR68 peptide, representing the immunodominant B cell epitope (Fig. 2A), or a full length recombinant protein (Fig. 2B) as capture antigens. Antibody responses to the protein were generally higher than responses to the peptide in all vaccine groups, presumably due to the presence of more B cell epitopes. All groups of mice immunized with VRP constructs had high levels of antibodies to either PyHEP17 protein or peptide, whereas immunization with DNA plasmids induced antibody responses to the PyHEP17 protein in all cases but not always to the peptide (data not shown). These data suggest that VRP

\section{B. Protein PyHEP17}
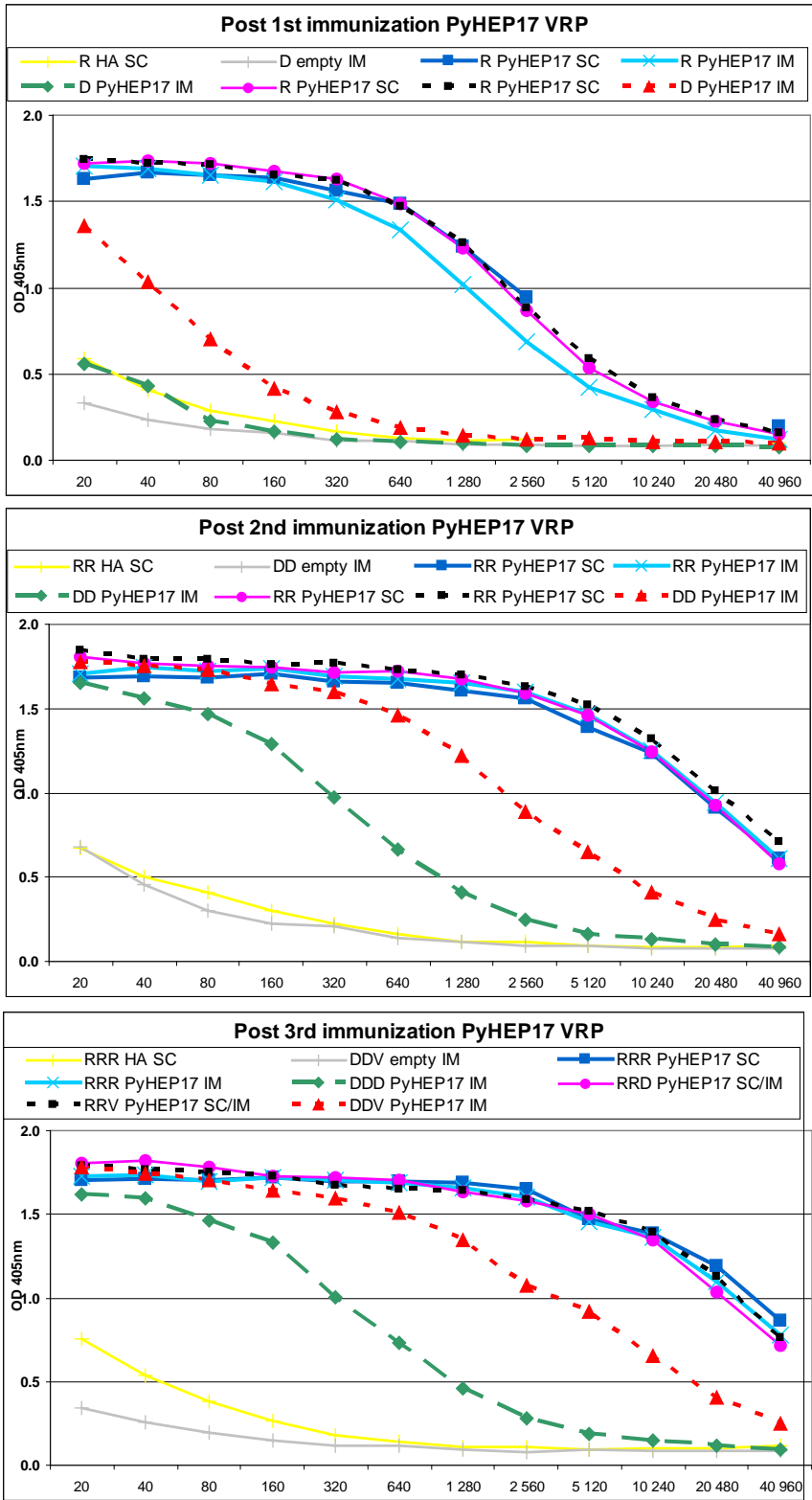

Fig. (2). Antigen-specific antibody responses induced by PyHEP17 VRP, measured by ELISA. Data show results from two separate immunization experiments with pooled sera $(n=6)$ collected 3 weeks after first, second, or third immunization. Serial dilutions of the sera are indicated in the X-axis. A: Antigen-specific antibody responses to PyHEP17 peptide induced by homologous or heterologous VRP boost immunization regimens. Note: timepoint for DR (6 wk interval) was parallel to RR (6 wk interval). B: Antigen-specific antibody responses to PyHEP17 protein induced by homologous or heterologous VRP prime immunization regimens. $\mathrm{R}=\mathrm{VEE} \mathrm{VRP} ; \mathrm{D}=\mathrm{DNA}$ plasmid; $\mathrm{V}=$ poxvirus; $\mathrm{SC}=$ subcutaneous; $\mathrm{IM}=$ intramuscular; $\mathrm{ID}=$ intradermal. 
immunization was able to stimulate responses against multiple B cell epitopes expressed on the protein, whilst DNA immunization stimulated responses to a more restricted set of epitopes, as shown by the lack of response to the immunodominant B cell epitope detected in some groups of mice. Thus, immunization with VRP via either the IM or SC route also increased the breadth of the response compared to DNA immunization (Fig. 2).

Regarding PyCSP, immunization with DNA (Fig. 3) or poxvirus (data not shown) expressing this antigen induces very high levels of antibodies to recombinant full-length protein, even after just one dose. Thus, an immune enhancement by vaccination with VRP was only apparent at the highest dilutions of sera after the third immunization. There were no differences between the SC and the IM routes for PyCSP-specific antibody titers.

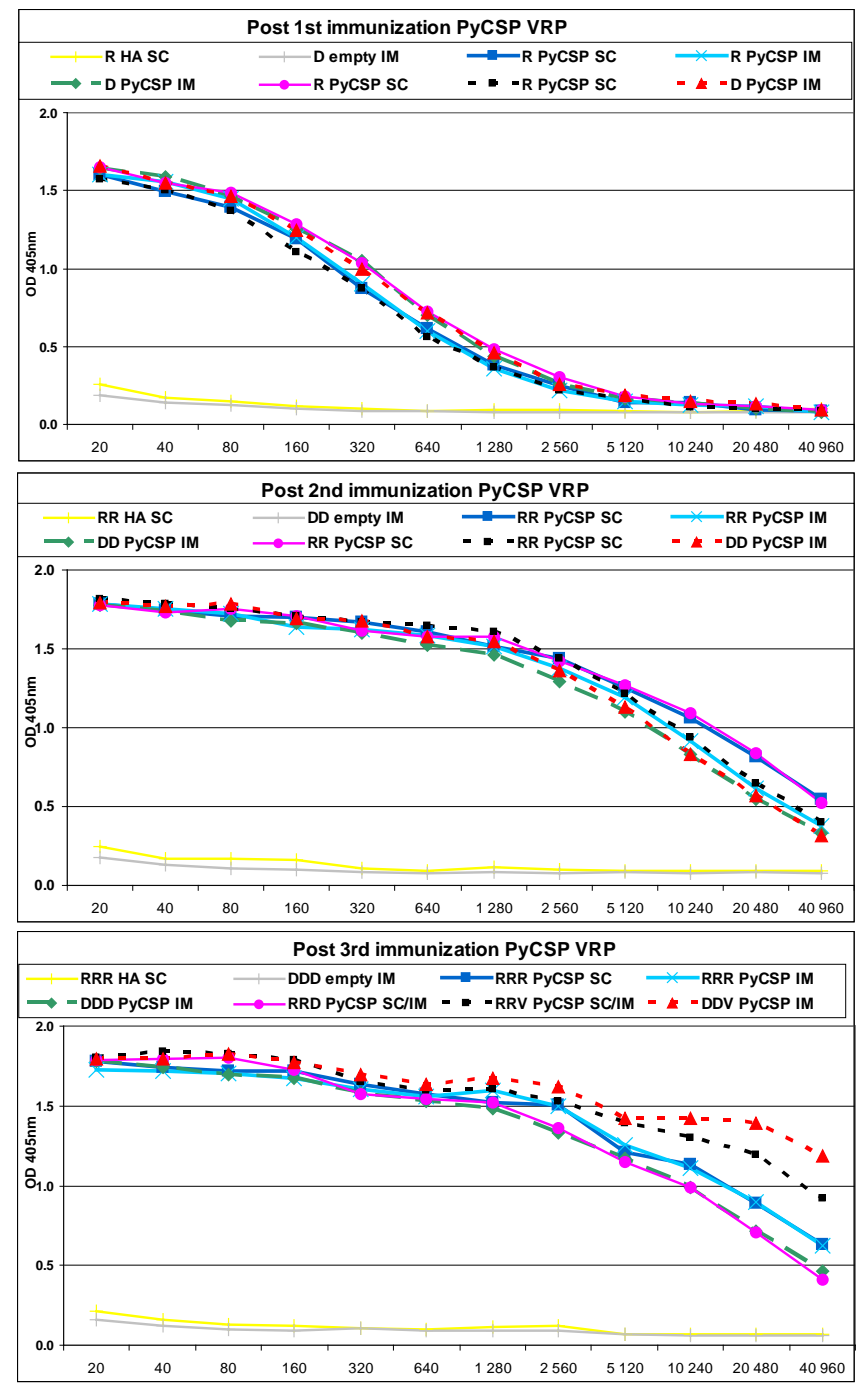

Fig. (3). Antigen-specific antibody responses to PyCSP induced by various routes of homologous or heterologous VRP prime immunization regimens, measured by ELISA. Serial dilutions of the sera are indicated in the $\mathrm{X}$-axis. $\mathrm{R}=\mathrm{VEE} \mathrm{VRP} ; \mathrm{D}=\mathrm{DNA}$ plasmid; $\mathrm{V}=$ poxvirus; $\mathrm{SC}=$ subcutaneous; $\mathrm{IM}=$ intramuscular; $\mathrm{ID}=$ intradermal.

\section{Cellular Immune Responses}

The effect of VRP immunization on $\mathrm{T}$ cell responses was different to that noted for antibody responses, and also varied between the two antigens tested. Homologous immunization with VRP encoding PyHEP17 administered via the SC, IM or ID routes did not enhance $\mathrm{T}$ cell responses as compared to DNA immunization IM, as measured by either IFN- $\gamma$ ELIspot (Fig. 4A) or ICS (Fig. 4B) (data not shown for ID). Other studies in our laboratory [41] have established that the IM route is the most immunogenic and protective for PyHEP17 and PyCSP DNA vaccines [41].

In contrast, homologous immunization with VRP encoding PyCSP, via either SC or IM routes, induced at least a 2-3 fold enhancement of IFN- $\gamma$ response relative to DNA immunization for all peptide epitopes tested regardless of dominance or phenotype, as measured by ELIspot (Fig. 4B) or CD4 ${ }^{+}$ICS (Fig. 5B), and a similarly increased response as measured by $\mathrm{CD}^{+}$ICS (Fig. 5B). ICS studies showed that the IFN- $\gamma$ responses induced by PyCSP VRP immunization were predominantly $\mathrm{CD}^{+} \mathrm{T}$ cell mediated (Fig. 5B). In fact, the profile of IFN- $\gamma \mathrm{CD} 8^{+} \mathrm{T}$ cell responses measured by ICS was almost identical to the profile of $\mathrm{T}$ cell responses measured by ELIspot (Fig. 4B).

There was no significant difference between administering the vaccine by the SC or the IM route, and both were superior to the ID route (data not shown).

For both antigens, ELIspots performed with frozen spleen cells showed the same profile of IFN- $\gamma$ response noted with fresh cells, although the magnitudes of response were slightly diminished (data not shown). ICS assays were not conducted with frozen cells.

Some non-specific background responses were evident in both ELIspot and ICS assays using splenocytes from mice immunized with VEE VRP encoding either PyHEP17 or PyCSP, and this background varied depending on the peptide epitope (data not presented), regardless of the antigen insert (Fig. 4). This non-specific background appeared to be associated with a bystander effect related to $\mathrm{CD} 4^{+} \mathrm{T}$ cells.

\section{Number of VRP Doses}

\section{Antibody Responses}

A single dose of VRP encoding PyHEP17 or PyCSP was very efficient at inducing high titers of antigen-specific antibodies (Figs. $2 \&$ 3). Nevertheless, antibody titers increased with subsequent immunizations (Fig. 1), although increments in immunogenicity after a third dose were not as marked (Figs. 2 \& 3).

\section{Cellular Immune Responses}

With regard to $\mathrm{T}$ cell responses, for both antigens, 3 doses were slightly but not significantly better than 2 doses, as evaluated by ELIspot and ICS (data not shown). T cell responses could also be induced by a single dose of VRP (data not shown).

In summary, for both antibody and $\mathrm{T}$ cell responses, immunization with a 3-dose VRP immunization regimen was only slightly more immunogenic than a 2-dose regimen, but at least for antibody responses, 2 doses were more immuno 
A.
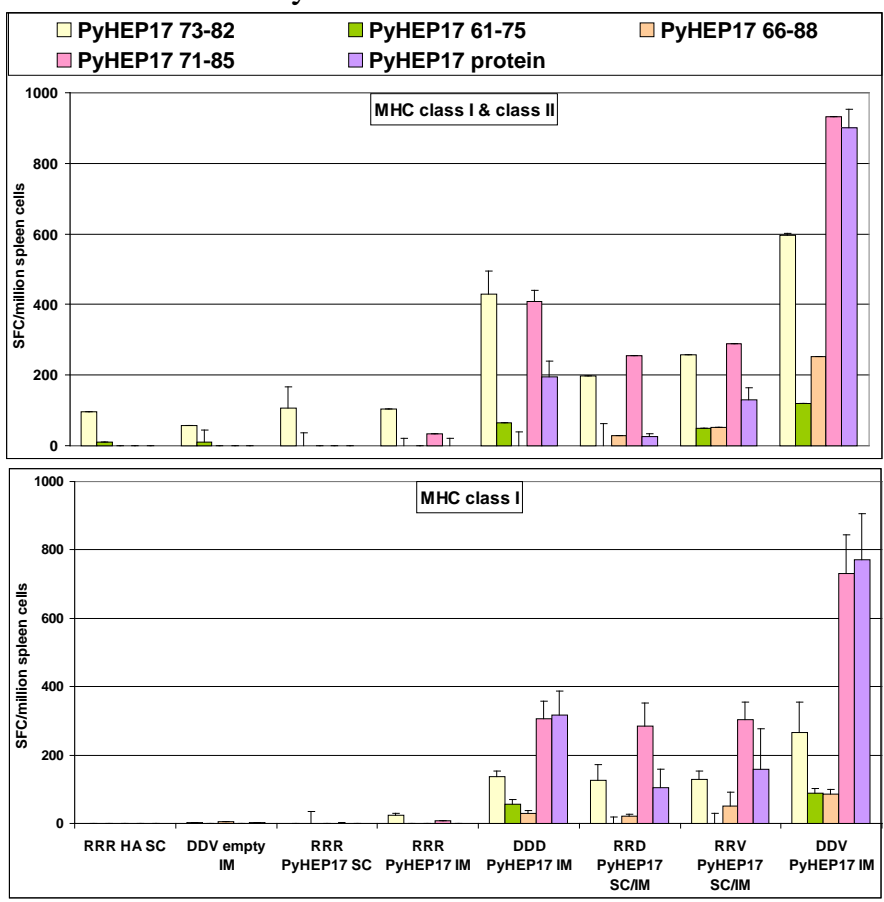

B.
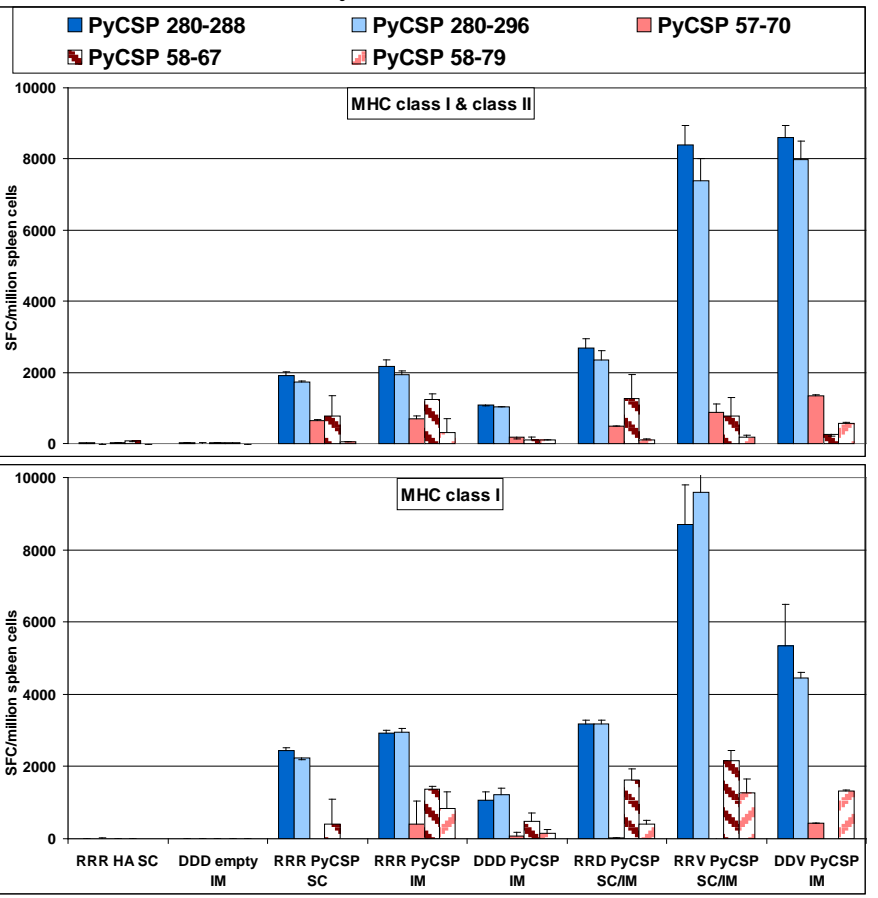

Fig. (4). Antigen-specific IFN- $\gamma$ responses to PyHEP17 (A) and PyCSP (B) induced after immunization with VRP, detected by ELIspot. Spleens (effector cells) were collected 3 or 5 weeks after the $3^{\text {rd }}$ immunization, pooled $(n=3)$, and IFN- $\gamma$ responses were measured. Target cells were MHC-matched A20.2J (MHC class I \& class II) or P815 (MHC class I) cells pulsed with synthetic peptides representing defined PyCSP or PyHEP17 epitopes (Table 1). Data are plotted as spot forming cells (SFC) per million spleen cells, averaged from two experiments performed at 3 and 5 weeks post boost. $\mathrm{R}=\mathrm{VEE}$ VRP; $\mathrm{D}=\mathrm{DNA}$ plasmid; $\mathrm{V}=$ poxvirus; $\mathrm{SC}=$ subcutaneous; IM = intramuscular; ID = in tradermal.

A.
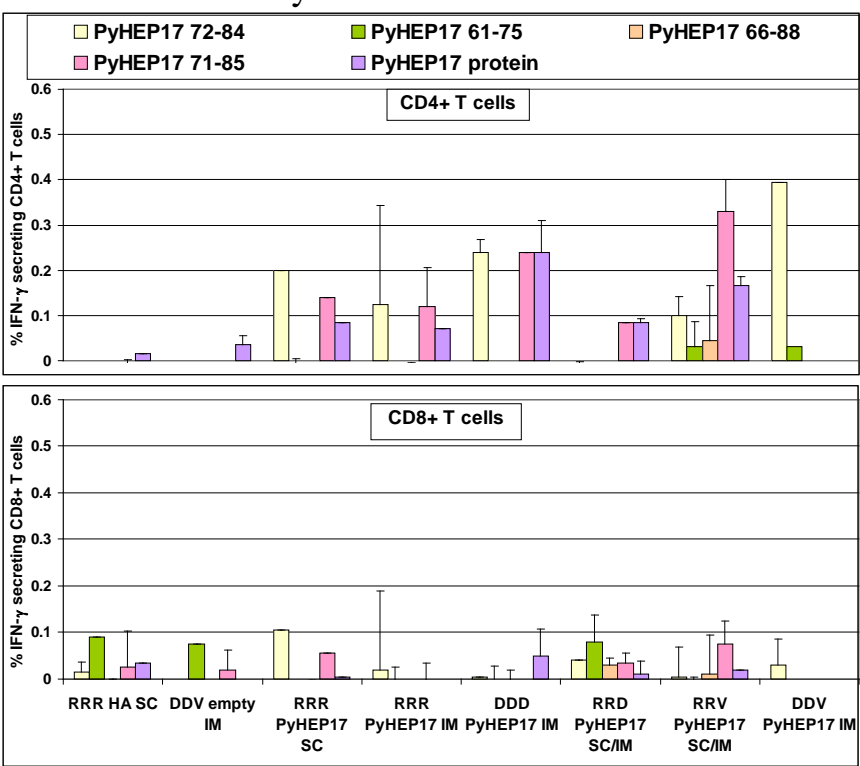

B. PyCSP
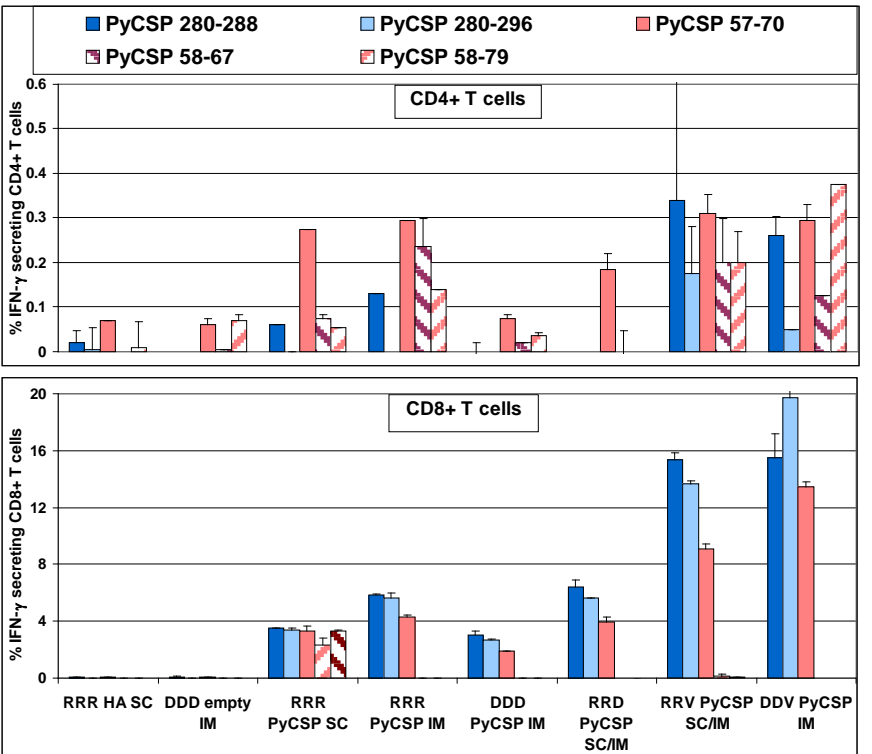

Fig. (5). Antigen-specific IFN- $\gamma$ responses to PyHEP17 (A) and PyCSP (B) induced after immunization with VRP, detected by intracellular cytokine staining. Spleens (effector cells) were collected 5 weeks after the $3^{\text {rd }}$ immunization, pooled $(n=3)$, and IFN- $\gamma$ responses were measured. Targets were MHC-matched A20.2J cells pulsed with synthetic peptides representing defined PyCSP or PyHEP17 epitopes. A: PyHEP17 induced $\mathrm{CD}^{+}$and $\mathrm{CD} 8^{+} \mathrm{T}$ cell secretion of IFN- $\gamma$ at low frequencies. B: PyCSP induced CD4 ${ }^{+}$and $\mathrm{CD} 8^{+} \mathrm{T}$ cell secretion of IFN- $\gamma$. R = VEE VRP; $\mathrm{D}=\mathrm{DNA}$ plasmid; $\mathrm{V}=$ poxvirus; $\mathrm{SC}=$ subcutaneous; $\mathrm{IM}=$ intramuscular; $\mathrm{ID}=$ intradermal. 
genic than 1 dose. This indicates that only one boost of VRP vaccine may be enough to induce an adequate immune response.

\section{Homologous vs. Heterologous Prime/Boost Immunization}

Different heterologous prime-boost strategies combining DNA (D), poxvirus (V) and replicon (R) vaccines were evaluated (Figs. 1-5).

\section{Antibody Responses}

We first examined the capacity of VRP to adequately prime antibody responses as assessed by ELISA, using recombinant PyHEP17 protein as capture antigen. Priming with VRP ( 2 doses) followed by a heterologous boost with DNA or poxvirus vaccines induced higher antibody levels than DNA prime followed by poxvirus boost, and comparable antibody levels to homologous immunizations with VRP (Fig. 2B). We next examined the capacity of VRP to boost the antibody response as assessed by IFAT and ELISA using the PyHEP17 MR68 peptide as capture antigen. Priming with plasmid DNA and boosting with VRP induced higher antibody titers to the PyHEP17 peptide than did homologous DNA immunization (Fig. 2A), but these titers were equivalent to those achieved by two homologous VRP immunizations (Figs. 1 \& 2A).

With regard to PyCSP, all homologous VRP and heterologous prime/boost immunization regimens were effective at inducing high titers of anti-PyCSP antibodies. However the heterologous DNA prime/poxvirus boost regimen was slightly more immunogenic than the VRP prime/poxvirus boost regimen, which was in turn slightly more immunogenic than the homologous replicon SC or IM routes of administration (Fig. 3).

\section{Cellular Immune Responses}

Heterologous prime/boost combinations involving VRP expressing either PyHEP17 or PyCSP were highly immunogenic with regard to cytokine responses, as evaluated by both IFN- $\gamma$ ELIspot and ICS for class $\mathrm{I} / \mathrm{CD}^{+}$or class II/CD4 ${ }^{+}$ (Figs. 4 and 5).

For CSP, the heterologous VRP prime/recombinant poxvirus boost regimen was markedly more immunogenic than the heterologous VRP prime/DNA boost regimen as demonstrated by both ELIspot (Fig. 4B) and ICS (Fig. 5B), and the response profiles were similar for both assays. For PyHEP17, there was no apparent difference in the vaccineinduced cellular responses following heterologous boosting with plasmid DNA or recombinant vaccinia virus. Consistent with the pattern observed with homologous PyCSP VRP immunization, the cellular immune responses induced by either VRP/poxvirus or VRP/DNA were mediated primarily by class I restricted $\mathrm{CD} 8^{+} \mathrm{T}$ cells (Figs. $4 \mathrm{~B}$ and $\mathbf{5 B}$ ).

In addition to evaluating antigen-specific responses of a $\mathrm{T}_{\mathrm{H}}$ 1-type cytokine (IFN- $\gamma$ ), we measured the profile of nonspecific $T_{H} 1$ and $T_{H} 2$ cytokines in serum after immunization with the different prime/boost vaccine combinations. Homologous or heterologous immunization with VRP resulted in significantly higher levels of circulating TNF- $\alpha, a T_{H} 1$ type cytokine, both for PyHEP17 (DDD vs. RRR, p = 0.0156; DDV vs. RRV, $\mathrm{p}=0.087$, calculated by the MannWhitney U test) and PyCSP (DDD vs. RRR, $\mathrm{p}=0.0374$; DDV vs. RRV, p = 0.0103) (Fig. 6A). In contrast, there was no significant difference in serum concentration of IL-4, a $\mathrm{T}_{\mathrm{H}}$ 2-type cytokine, in mice immunized with PyCSP DNA, poxvirus or VRP vaccines (DDD vs. RRR, $\mathrm{p}=0.8099$; DDV vs. RRV, p = 0.3358) (Fig. 6B), and there was a modest increase in IL-4 responses in mice immunized with PyHEP17 VRP (DDD vs. RRR, $\mathrm{p}=0.036$; DDV vs. RRV, $\mathrm{p}=0.0247$ ). The levels of the other cytokines measured, IL-2, IL-5, IFN- $\gamma$ were too low to be analyzed statistically.

\section{Longevity of Antibody Responses}

To evaluate the durability of the antibody responses, serum was harvested at 4.5 months after the $3^{\text {rd }}$ immunization, and the IgG titers measured by ELISA against recombinant PyHEP17 protein. As shown in Fig. (7), antibody responses at this 4.5 month timepoint remained very high for all groups, and were equivalent to responses detected 2-3 weeks after the $3^{\text {rd }}$ immunization. Interestingly, after 4.5 months, antibody levels were comparable in mice that had received either 2 or 3 doses of DNA or VRP vaccines (data shown after 3 homologous immunizations or 2 heterologous DNA prime/VRP boost). Consistent with this, we also noted that an additional boost given at 4.5 months after the $3^{\text {rd }}$ immuni-
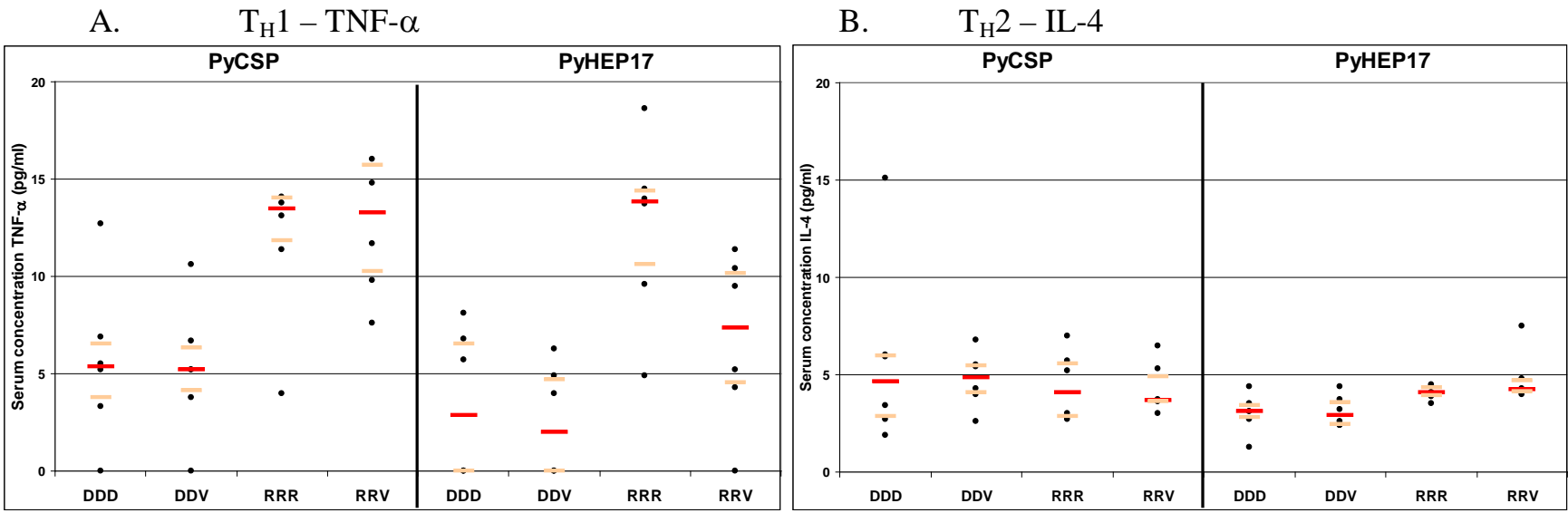

Fig. (6). $\mathrm{T}_{\mathrm{H}} 1 / \mathrm{T}_{\mathrm{H}} 2$ cytokines in serum induced after immunization with VRP, measured by cytometric bead array. Horizontal lines indicate median and percentile $(25 \%$ and $75 \%)$ levels. A: TNF- $\alpha$ responses $\left(\mathrm{T}_{\mathrm{H}} 1\right)$. B: IL-4 responses $\left(\mathrm{T}_{\mathrm{H}} 2\right) . \mathrm{R}=\mathrm{VEE}$ VRP; $\mathrm{D}=\mathrm{DNA}$ plasmid; V = poxvirus. 

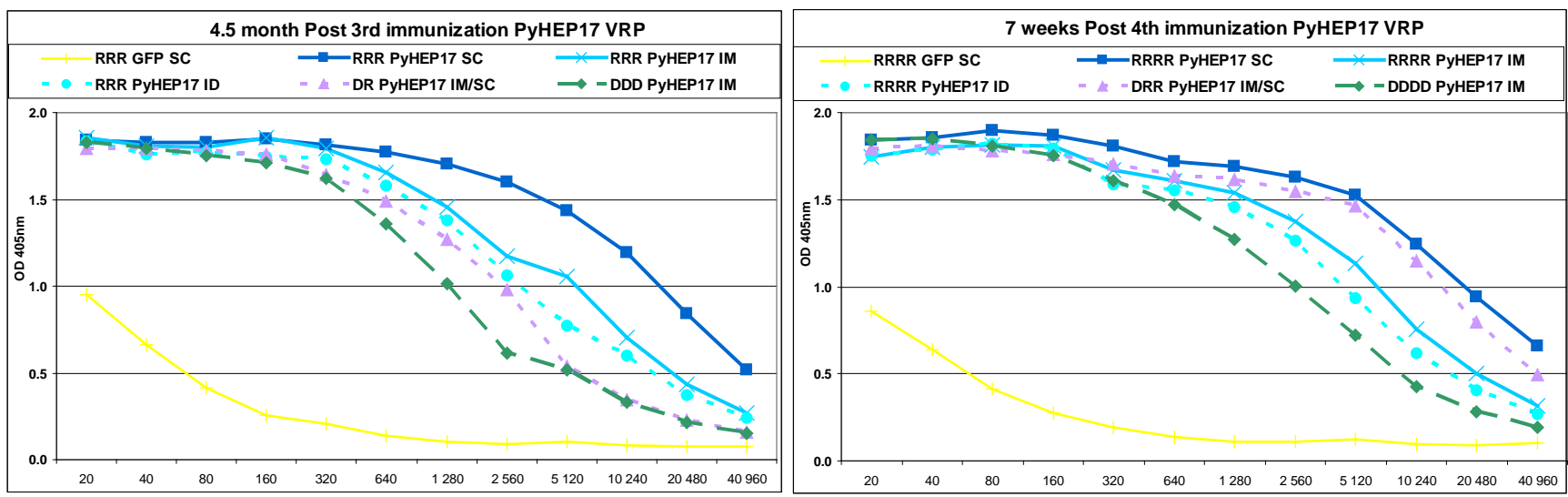

Fig. (7). Longevity of antigen-specific antibody responses to PyHEP17 protein induced by various routes of homologous or heterologous VRP SC boost vaccination strategies. Serial dilutions of the sera are indicated in the X-axis. $\mathrm{R}=\mathrm{VEE}$ VRP; $\mathrm{D}=\mathrm{DNA}$ plasmid; V $=$ poxvirus.

zation did not enhance antibody responses above the level attained by 2 or 3 doses (Fig. 7). The only group of mice in which an additional late boost appeared to be beneficial was the DNA prime/VRP boost, where a second booster of VRP resulted in enhanced antibody responses (Fig. 7). Taken together, data indicate that high and sustained antibody responses are induced by both homologous and heterologous VRP immunization regimens, with as few as 2 immunizing doses.

\section{DISCUSSION}

To enhance protective efficacy of current vaccines against pathogens such as Plasmodium spp. that undergo intracellular and extracellular stages of development during a complex life cycle, more efficacious vaccine delivery systems are required that are capable of inducing both high antigen-specific $\operatorname{IgG}$ antibody titers and potent $\mathrm{T}_{\mathrm{H}} 1$ cellular mediated responses. These are immune effector mechanisms that have been associated with protective immunity in humans [3] and rodent malaria models [5, 7], respectively. To enhance the magnitude of immune responses, it would be desirable that such vaccine delivery systems facilitate high level of antigen expression while retaining some of the attractive features of DNA vaccination technology, particularly the simplicity of design, modification, large-scale production, and potential for multi-antigen and multi-pathogen vaccination [42-45]. Here, we show that VRP encoding two $P$. yoelii pre-erythrocytic stage antigens, used alone or in combination with DNA or poxvirus vaccines in heterologous prime/boost immunization regimens, are very efficient at augmenting the magnitude of antibody responses (Figs. 1, 2, 3 ) and of IFN- $\gamma$ production by $\mathrm{CD}^{+}$and $\mathrm{CD} 8^{+} \mathrm{T}$ cells (Figs. $\mathbf{4 , 5}$ ) in a murine model of malaria. We also compared different routes of administration of the VRP vaccines and found that SC and IM routes were equally efficient and superior to ID for the induction of antibody and $\mathrm{T}$ cell responses.

Homologous VRP immunization was particularly effective at inducing robust antigen-specific antibody responses. In our model, VRP were capable of overcoming the traditionally low immunogenicity of the PyHEP17 antigen when delivered as DNA vaccine by dramatically enhancing spe- cific IgG antibody responses as assessed against whole parasite blood stages (Fig. 1), a synthetic peptide and a recombinant protein (Fig. 2). This was manifested after even a single dose of VRP, and titers generally improved with subsequent immunizations, with as little as one boost being enough to achieve considerably high titers. Antibody responses remained high even after several months post vaccination, therefore responses plateau and were not boosted by a $4^{\text {th }}$ dose (Fig. 7). The immune enhancement effect of VRP was most apparent for PyHEP17, not for the PyCSP antigen, because very low antibody responses against PyHEP17 are usually elicited in other vaccine platforms, whereas most vaccine platforms are effective at inducing high antibody responses against PyCSP. Thus, although antibody titers obtained by homologous PyCSP VRP were also enhanced compared to homologous DNA immunization, this effect was only apparent at the highest dilutions and after 3 immunizations (Fig. 3). Heterologous prime/boost combinations of VRP with either DNA or poxvirus vaccines were equal or superior to homologous VRP immunization or to heterologous DNA prime/poxvirus boost at inducing high antibody titers (Figs. 1, 2, 3).

With regard to VRP encoding PyCSP, homologous VRP immunizations were markedly superior to homologous DNA immunizations, even after just 2 doses, and the IFN- $\gamma$ responses were mediated predominantly by $\mathrm{CD} 8^{+}$effector $\mathrm{T}$ cells. Also noteworthy, heterologous VRP prime/poxvirus boost immunization with PyCSP was equal or better than the previously considered gold standard combination of DNA prime/poxvirus boost, indicating a great potential of VRP for priming protective immune responses. Interestingly, this capacity of VRP to boost PyCSP-specific cellular immune responses was not observed with the PyHEP17 antigen, where VRPs had a remarkable capacity to boost the antigenspecific antibody response as noted above.

Evaluation of cytokines in serum samples indicated that immunization with VRP encoding PyHEP17 or PyCSP induced predominantly a $\mathrm{T}_{\mathrm{H}} 1$ immune activation, which is the type of cellular immune response also induced by DNA and poxvirus vaccines, and which is thought to be required for liver-stage immunity (Fig. 6). $\mathrm{T}_{\mathrm{H}} 1$ immune responses in 
blood and TNF- $\alpha$ in particular have been associated with protective immunity to malaria [46] as well as with pathology when levels are excessive [47]. In contrast, IL-4 levels remained comparable to those found after immunization with DNA plasmids.

To determine if the increased immunogenicity induced by VRP vaccines translated into better liver stage protection we challenged immunized mice with infective sporozoites, as described [48], in two separate experiments. However, these challenge experiments did not work, probably due to the suboptimal quality of the sporozoites obtained (data not shown). Although protection could not be formally demonstrated in these sets of experiments, the type of immune responses induced by our VRP vaccines has been consistently associated with protection in many previous studies and we believe that the enhanced immunogenicity reported here will indeed translate to enhanced protection.

\section{CONCLUSION}

VEE VRP vaccines offer advantages over other recombinant virus delivery systems under vaccine development. In contrast to poxvirus [22], or adenovirus immunization with VRP does not appear to induce anti-vector responses that inhibit subsequent booster immunizations [16]. In addition, there is low prevalence of immune responses to VEE in the population, which represents a problem with adenovirus vectors [23]. Moreover, the predilection of VRP for targeting dendritic cells results in improved antigen presentation [17], and their inability to revert to an infectious state (replicationdefective "suicide" vectors) makes them very attractive and safe vaccines. These valuable features of VRP together with the enhancement of both antibody and cellular responses demonstrated here for two malaria antigens provides support for the development of vaccines to combat infectious agents for humans using this delivery system in homologous as well as heterologous prime/boost strategies.

\section{ACKNOWLEDGEMENTS}

We thank Thomas Luke and Gary Brice for preliminary experiments on VRP doses titrations, Keith Limbach and Kalpana Gowda for the PyHEP17 poxvirus construct, David Bacon for the recombinant PyHEP17 protein, Norma Graber for technical assistance with $\mathrm{T}$ cell assays, and William Rogers for statistical support. The views expressed in this article are those of the authors and do not necessarily reflect the official policy or position of the Department of the Navy, Department of Defense, nor the U.S. Government. Work was supported by funds allocated to the Naval Medical Research Center by the Office of Naval Research (work units 61152N.00004.001.A0118 and 62236.02PR11.459.A0258).

\section{LIST OF ABBREVIATIONS}

$\begin{array}{ll}\text { CI } & =\text { confidence interval } \\ \text { FACS } & =\text { fluorescent activated cell sorting } \\ \text { ICS } & =\text { intracellular cytokine staining } \\ \text { ID } & =\text { intradermal } \\ \text { IFAT } & =\text { indirect fluorescent antibody test } \\ \text { IM } & =\text { intramuscular } \\ \text { IU } & =\text { infectious units }\end{array}$

$\begin{array}{ll}\text { IV } & =\text { intravenous } \\ \text { P. yoelii } & =\text { Plasmodium yoelii } \\ \text { PyCSP } & =\text { P. yoelii circumsporozoite protein } \\ \text { PyHEP17 } & =\text { P. yoelii hepatocyte erythrocyte protein; } \\ \text { SC } & =\text { subcutaneous } \\ \text { SD } & =\text { standard deviation } \\ \text { SFC } & =\text { spot forming cells } \\ \text { VEE } & =\text { Venezuelan equine encephalitis } \\ \text { VRP } & =\text { virus-like replicon particle }\end{array}$

\section{REFERENCES}

[1] Garnham, P.C.C. Malaria Parasites and other Haemosporidia. Blackwell Scientific Publications: Oxford, 1966.

[2] Hoffman, S.L.; Goh, L.M.; Luke, T.C.; Schneider, I.; Le, T.P.; Doolan, D.L.; Sacci, J.; de la Vega, P.; Dowler, M.; Paul, C.; Gordon, D.M.; Stoute, J.A.; Church, L.W.; Sedegah, M.; Heppner, D.G.; Ballou, W.R.; Richie, T.L. Protection of humans against malaria by immunization with radiation-attenuated Plasmodium falciparum sporozoites. J. Infect. Dis., 2002, 185, 1155-64.

[3] Cohen, S.; Mc, G.I.; Carrington, S. Gamma-globulin and acquired immunity to human malaria. Nature, 1961, 192, 733-37.

[4] Reed, Z.H.; Friede, M.; Kieny, M.P. Malaria vaccine development: progress and challenges. Curr. Mol. Med., 2006, 6, 231-45.

[5] Sedegah, M.; Hedstrom, R.; Hobart, P.; Hoffman, S.L. Protection against malaria by immunization with plasmid DNA encoding circumsporozoite protein. Proc. Natl. Acad. Sci. USA, 1994, 91, 986670.

[6] Doolan, D.L.; Hedstrom, R.C.; Rogers, W.O.; Charoenvit, Y.; Rogers, M.; De la Vega, P.; Hoffman, S.L. Identification and characterization of the protective hepatocyte erythrocyte protein $17 \mathrm{kDa}$ gene of Plasmodium yoelii, homolog of Plasmodium falciparum exported protein 1. J. Biol. Chem., 1996, 271, 17861-68.

[7] Doolan, D.L.; Sedegah, M.; Hedstrom, R.C.; Hobart, P.; Charoenvit, Y.; Hoffman, S.L. Circumventing genetic restriction of protection against malaria with multi-gene DNA immunization: CD8+ T cell, interferon- $\gamma$, and nitric oxide dependent immunity. J. Exp. Med., 1996, 183, 1739-46.

[8] Sedegah, M.; Jones, T.R.; Kaur, M.; Hedstrom, R.; Hobart, P.; Tine, J.A.; Hoffman, S.L. Boosting with recombinant vaccinia increases immunogenicity and protective efficacy of malaria DNA vaccine. Proc. Natl. Acad. Sci. USA, 1998, 95, 7648-53.

[9] Dobaño, C.; Doolan, D.L. Identification of minimal CD8+ and CD4+ T cell epitopes in the Plasmodium yoelii hepatocyte erythrocyte protein 17kDa. Mol. Immunol., 2007, 44,3037-48.

[10] Doria-Rose, N.A.; Haigwood, N.L. DNA vaccine strategies: candidates for immune modulation and immunization regimens. Methods, 2003, 31, 207-16.

[11] Sedegah, M.; Weiss, W.; Sacci, J.B. Jr.; Charoenvit, Y.; Hedstrom, R.; Gowda, K.; Majam, V.F.; Tine, J.; Kumar, S.; Hobart, P.; Hoffman, S.L. Improving protective immunity induced by DNAbased immunization: priming with antigen and GM-CSF-encoding plasmid DNA and boosting with antigen-expressing recombinant poxvirus. J. Immunol., 2000, 164, 5905-12.

[12] Moore, A.C.; Hill, A.V. Progress in DNA-based heterologous prime-boost immunization strategies for malaria. Immunol. Rev., 2004, 199, 126-43.

[13] Woodland, D.L. Jump-starting the immune system: prime-boosting comes of age. Trends Immunol., 2004, 25,98-104.

[14] Schlesinger, S.; Dubensky, T.W. Alphavirus vectors for gene expression and vaccines. Curr. Opin. Biotechnol., 1999, 10, 434-39.

[15] Berglund, P.; Fleeton, M.N.; Smerdou, C.; Liljestrom, P. Immunization with recombinant Semliki Forest virus induces protection against influenza challenge in mice. Vaccine, 1999, 17, 497-507.

[16] Rayner, J.O.; Dryga, S.A.; Kamrud, K.I. Alphavirus vectors and vaccination. Rev. Med. Virol., 2002, 12, 279-96.

[17] Ying, H.; Zaks, T.Z.; Wang, R.F.; Irvine, K.R.; Kammula, U.S.; Marincola, F.M.; Leitner, W.W.; Restifo, N.P. Cancer therapy using a self-replicating RNA vaccine. Nat. Med., 1999, 5, 823-27. 
[18] Dubensky, T.W. Jr.; Liu, M.A.; Ulmer, J.B. Delivery systems for gene-based vaccines. Mol. Med., 2000, 6, 723-32.

[19] Pushko, P.; Parker, M.; Ludwig, G.V.; Davis, N.L.; Johnston, R.E.; Smith, J.F. Replicon-helper systems from attenuated Venezuelan equine encephalitis virus: expression of heterologous genes in vitro and immunization against heterologous pathogens in vivo. Virology, 1997, 239, 389-401.

[20] MacDonald, G.H.; Johnston, R.E. Role of dendritic cell targeting in Venezuelan equine encephalitis virus pathogenesis. J. Virol., 2000, 74,914-22.

[21] Caley, I.J.; Betts, M.R.; Irlbeck, D.M.; Davis, N.L.; Swanstrom, R.; Frelinger, J.A.; Johnston, R.E. Humoral, mucosal, and cellular immunity in response to a human immunodeficiency virus type $1 \mathrm{im}-$ munogen expressed by a Venezuelan equine encephalitis virus vaccine vector. J. Virol., 1997, 71,3031-38.

[22] Sharpe, S.; Polyanskaya, N.; Dennis, M.; Sutter, G.; Hanke, T.; Erfle, V.; Hirsch, V.; Cranage, M. Induction of simian immunodeficiency virus (SIV)-specific CTL in rhesus macaques by vaccination with modified vaccinia virus Ankara expressing SIV transgenes: influence of pre-existing anti-vector immunity. J. Gen. Virol., 2001, 82, 2215-23.

[23] Barouch, D.H.; Pau, M.G.; Custers, J.H.; Koudstaal, W.; Kostense, S.; Havenga, M.J.; Truitt, D.M.; Sumida, S.M.; Kishko, M.G.; Arthur, J.C.; Korioth-Schmitz, B.; Newberg, M.H.; Gorgone, D.A.; Lifton, M.A.; Panicali, D.L.; Nabel, G.J.; Letvin, N.L.; Goudsmit, J. Immunogenicity of recombinant adenovirus serotype 35 vaccine in the presence of pre-existing anti-Ad5 immunity. J. Immunol., 2004, 172, 6290-97.

[24] Pushko, P.; Geisbert, J.; Parker, M.; Jahrling, P.; Smith, J. Individual and bivalent vaccines based on alphavirus replicons protect guinea pigs against infection with Lassa and Ebola viruses. J. Virol., 2001, 75, 11677-85.

[25] Hevey, M.; Negley, D.; Pushko, P.; Smith, J.; Schmaljohn, A. Marburg virus vaccines based upon alphavirus replicons protect guinea pigs and nonhuman primates. Virology, 1998, 251, 28-37.

[26] Lee, J.S.; Pushko, P.; Parker, M.D.; Dertzbaugh, M.T.; Smith, L.A.; Smith, J.F. Candidate vaccine against botulinum neurotoxin serotype A derived from a Venezuelan equine encephalitis virus vector system. Infect. Immun., 2001, 69, 5709-15.

[27] Davis, N.L.; Caley, I.J.; Brown, K.W.; Betts, M.R.; Irlbeck, D.M.; McGrath, K.M.; Connell, M.J.; Montefiori, D.C.; Frelinger, J.A.; Swanstrom, R.; Johnson, P.R.; Johnston, R.E. Vaccination of macaques against pathogenic simian immunodeficiency virus with Venezuelan equine encephalitis virus replicon particles. J. Virol., 2000, 74, 371-78.

[28] Lee, J.S.; Hadjipanayis, A.G.; Welkos, S.L. Venezuelan equine encephalitis virus-vectored vaccines protect mice against anthrax spore challenge. Infect. Immun., 2003, 71, 1491-96.

[29] Pushko, P.; Bray, M.; Ludwig, G.V.; Parker, M.; Schmaljohn, A.; Sanchez, A.; Jahrling, P.B.; Smith, J.F. Recombinant RNA replicons derived from attenuated Venezuelan equine encephalitis virus protect guinea pigs and mice from Ebola hemorrhagic fever virus. Vaccine, 2000, 19, 142-53.

[30] Olinger, G.G.; Bailey, M.A.; Dye, J.M.; Bakken, R.; Kuehne, A.; Kondig, J.; Wilson, J.; Hogan, R.J.; Hart, M.K. Protective cytotoxic T-cell responses induced by venezuelan equine encephalitis virus replicons expressing Ebola virus proteins. J. Virol., 2005, 79, 14189-96.

[31] Johnston, R.E.; Johnson, P.R.; Connell, M.J.; Montefiori, D.C.; West, A.; Collier, M.L.; Cecil, C.; Swanstrom, R.; Frelinger, J.A.; Davis, N.L. Vaccination of macaques with SIV immunogens delivered by Venezuelan equine encephalitis virus replicon particle vectors followed by a mucosal challenge with SIVsmE660. Vaccine, 2005, 23, 4969-79.
[32] Thomas, C.E.; Zhu, W.; Van Dam, C.N.; Davis, N.L.; Johnston, R.E.; Sparling, P.F. Vaccination of mice with gonococcal TbpB expressed in vivo from Venezuelan equine encephalitis viral replicon particles. Infect. Immun., 2006, 74, 1612-20.

[33] Luke, C.J.; Carner, K.; Liang, X.; Barbour, A.G. An OspA-based DNA vaccine protects mice against infection with Borrelia burgdorferi. J. Infect. Dis., 1997, 175, 91-97.

[34] Charoenvit, Y.; Leef, M.F.; Yuan, L.F.; Sedegah, M.; Beaudoin, R.L. Characterization of Plasmodium yoelii monoclonal antibodies directed against stage-specific sporozoite antigens. Infect. Immun., 1987, 55, 604-08.

[35] Charoenvit, Y.; Mellouk, S.; Cole, C.; Bechara, R.; Leef, M.F.; Sedegah, M.; Yuan, L.F.; Robey, F.A.; Beaudoin, R.L.; Hoffman, S.L. Monoclonal, but not polyclonal, antibodies protect against Plasmodium yoelii sporozoites. J. Immunol., 1991, 146, 1020-25.

[36] Charoenvit, Y.; Majam, V.F.; Corradin, G.; Sacci, J.B. Jr.; Wang, R.; Doolan, D.L.; Jones, T.R.; Abot, E.; Patarroyo, M.E.; Guzman, F.; Hoffman, S.L. CD4(+) T-cell- and gamma interferon-dependent protection against murine malaria by immunization with linear synthetic peptides from a Plasmodium yoelii 17-kilodalton hepatocyte erythrocyte protein. Infect. Immun., 1999, 67, 5604-14.

[37] Weiss, W.R.; Mellouk, S.; Houghten, R.A.; Sedegah, M.; Kumar, S.; Good, M.F.; Berzofsky, J.A.; Miller, L.H.; Hoffman, S.L. Cytotoxic $\mathrm{T}$ cells recognize a peptide from the circumsporozoite protein on malaria-infected hepatocytes. J. Exp. Med., 1990, 171, 763-73.

[38] Franke, E.D.; Sette, A.; Sacci, J. Jr.; Southwood, S.; Corradin, G.; Hoffman, S.L. A subdominant CD8(+) cytotoxic T lymphocyte (CTL) epitope from the Plasmodium yoelii circumsporozoite protein induces CTLs that eliminate infected hepatocytes from culture. Infect Immun., 2000, 68, 3403-11.

[39] Del Giudice, G.; Grillot, D.; Renia, L.; Muller, I.; Corradin, G.; Louis, J.A.; Mazier, D.; Lambert, P.H. Peptide-primed CD4+ cells and malaria sporozoites. Immunol. Lett., 1990, 25, 59-63.

[40] Renia, L.; Marussig, M.S.; Grillot, D.; Pied, S.; Corradin, G.; Miltgen, F.; Del Giudice, G.; Mazier, D. In vitro activity of CD4+ and CD8+ T lymphocytes from mice immunized with a synthetic malaria peptide. Proc. Natl. Acad. Sci. USA, 1991, 88, 7963-67.

[41] Doolan, D.L.; Hedstrom, R.C.; Wang, R.; Sedegah, M.; Scheller, L.F.; Hobart, P.; Norman, J.A.; Hoffman, S.L. DNA vaccines for malaria: the past, the present, \& the future. Indian J. Med. Res., 1997, 106, 109-19.

[42] Srivastava, I.K.; Liu, M.A. Gene vaccines. Ann. Intern. Med., 2003 , $138,550-59$.

[43] Kirman, J.R.; Seder, R.A. DNA vaccination: the answer to stable, protective T-cell memory? Curr. Opin. Immunol., 2003, 15, 47176.

[44] Kaslow, D.C. A potential disruptive technology in vaccine development: gene-based vaccines and their application to infectious diseases. Trans. R Soc. Trop Med. Hyg., 2004, 98, 593-601.

[45] Ulmer, J.B.; Wahren, B.; Liu, M.A. Gene-based vaccines: recent technical and clinical advances. Trends Mol. Med., 2006, 12, 21622.

[46] Stevenson, M.M.; Tam, M.F.; Wolf, S.F.; Sher, A. IL-12-induced protection against blood-stage Plasmodium chabaudi AS requires IFN-gamma and TNF-alpha and occurs via a nitric oxidedependent mechanism. J. Immunol., 1995, 155, 2545-56.

[47] Grau, G.E.; Taylor, T.E.; Molyneux, M.E.; Wirima, J.J.; Vassalli, P.; Hommel, M.; Lambert, P.H. Tumor necrosis factor and disease severity in children with falciparum malaria. N. Engl. J. Med. 1989, 320, 1586-15891.

[48] Dobaño, C.; McTague, A.; Sette, A.; Hoffman, S.L.; Rogers, W.O.; Doolan, D.L. Mutating the anchor residues associated with MHC binding inhibits and deviates CD8+ T cell mediated protective immunity against malaria. Mol. Immunol., 2007, 44, 2235-48.

This is an open access article licensed under the terms of the Creative Commons Attribution Non-Commercial License (http://creativecommons.org/licenses/by-nc/3.0/) which permits unrestricted, non-commercial use, distribution and reproduction in any medium, provided the work is properly cited. 